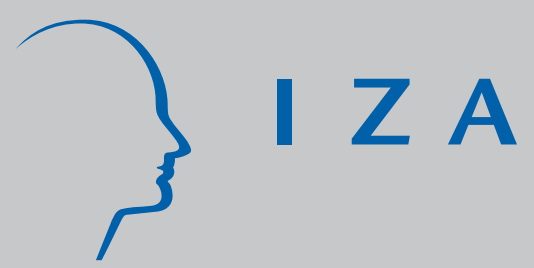

IZA DP No. 660

Do Large Employers Pay More in Developing Countries?

The Case of Five African Countries

Eric Strobl

Robert Thornton

December 2002 


\title{
Do Large Employers Pay More in Developing Countries? The Case of Five African Countries
}

\author{
Eric Strobl \\ CORE, Catholic University of Louvain \\ and IZA Bonn \\ Robert Thornton \\ Lehigh University \\ Discussion Paper No. 660 \\ Dezember 2002 \\ IZA \\ P.O. Box 7240 \\ D-53072 Bonn \\ Germany \\ Tel.: +49-228-3894-0 \\ Fax: +49-228-3894-210 \\ Email: iza@iza.org
}

This Discussion Paper is issued within the framework of IZA's research area Labor Markets in Transition Countries. Any opinions expressed here are those of the author(s) and not those of the institute. Research disseminated by IZA may include views on policy, but the institute itself takes no institutional policy positions.

The Institute for the Study of Labor (IZA) in Bonn is a local and virtual international research center and a place of communication between science, politics and business. IZA is an independent, nonprofit limited liability company (Gesellschaft mit beschränkter Haftung) supported by the Deutsche Post AG. The center is associated with the University of Bonn and offers a stimulating research environment through its research networks, research support, and visitors and doctoral programs. IZA engages in (i) original and internationally competitive research in all fields of labor economics, (ii) development of policy concepts, and (iii) dissemination of research results and concepts to the interested public. The current research program deals with (1) mobility and flexibility of labor, (2) internationalization of labor markets, (3) welfare state and labor market, (4) labor markets in transition countries, (5) the future of labor, (6) evaluation of labor market policies and projects and (7) general labor economics.

IZA Discussion Papers often represent preliminary work and are circulated to encourage discussion. Citation of such a paper should account for its provisional character. A revised version may be available on the IZA website (www.iza.org) or directly from the author. 
IZA Discussion Paper No. 660

December 2002

\section{ABSTRACT}

\section{Do Large Employers Pay More in Developing Countries? The Case of Five African Countries*}

Using comparable data sets for five African countries we estimate, and evaluate possible explanations for, the employer size wage effect across these. Our results indicate, just as has been generally found for other developing and developed nations, that apart from observable worker characteristics most potential theories cannot explain very much of the wage premium received in larger firms. Moreover, we find that the employer size wage effect does not differ greatly across the five African countries. Like other developing nations it is, however, larger than that found in the industrialised world, and, unlike the industrialised world, larger for white than blue collar workers. Additionally, data for one of the African countries in conjunction with other tentative evidence suggests that this may in part be because skill biased technology affects the firm size wage distribution across skill groups in developing countries more.

JEL Classification: J3, O1

Keywords: $\quad$ employer size wage effect, Cameroon, Ghana, Kenya, Zambia, Zimbabwe

Corresponding author:

Eric Strobl

CORE

Université Catholique Louvain

Voie du Roman Pays 34

1348 Louvain-la-Neuve

Belgium

Tel.: +32 10474328

Fax: +32 10474301

Email: strobl@core.ucl.ac.be

\footnotetext{
* We are grateful to the CSAE for provision of the data. In particular we would like to thank Francis Teal for his help and advice on numerous matters regarding the data. Thanks are also due to Holger Goerg for comments.
} 


\section{Section I: Introduction}

The fact that larger firms appear to pay higher wages than smaller firms for equally productive workers was noted as early as by Moore (1911). However, despite a reemergence of interest in this aspect of the labour market in the late $1980 \mathrm{~s}^{1}$, the availability of more and richer data sets, and the use of more sophisticated statistical techniques, there has been little consensus on the cause of this empirical artifact. $^{2}$ This phenomena is also not solely confined to the developed world - recently a number of studies have confirmed the existence of what is often termed the firm size wage effect in a variety of developing nations as well; see, for example, Little et al (1987), Schaffner (1998), Mazumdar and Mazaheri (1999), Velenchik (1997), and Marcelle and Strobl (2001). Moreover, the size of the wage premium associated with working in larger firms appears to be larger in developing than developed countries, a feature that also remains as of yet unexplained.

Unearthing the causes of the employer size wage effect in developing countries, particularly given its apparent greater size relative to the industrialised world, is important for a number of reasons. Firstly, because labour markets in developing countries differ in many respects from those in the developed world, exploring the firm size wage premium in these countries can provide further pieces to the puzzle. Secondly, the employer size wage effect is likely to add to income inequality which tends to be high in developing countries. While clearly the understanding and reduction of income inequality is a complex issue, if the firm size wage effect is large, its role in policy formulation cannot be ignored. Related to this, development agencies and policy makers often view small firms as alternative employers for surplus labour,

\footnotetext{
${ }^{1}$ See Brown and Medoff (1989) and Evans and Leighton (1989).

${ }^{2}$ For a recent review of the literature see Oi and Idson (1999).
} 
and as a means to achieve more productive employment and more equitable distribution of the benefits of growth (Biggs et al, 1998).

In this paper we use the Regional Programme for Enterprise Development (RPED) database to investigate the firm size wage effect for five African countries, namely Cameroon, Ghana, Kenya, Zambia, and Zimbabwe. Using this data to explore the firm size wage premium has a number of advantages. While most theoretical explanations for the employer size wage effect stress the matching of employers and employees as the driving force, traditionally studies have either used worker or workplace data independently. Only in the last few years have researchers gained access to employer employee matched data that has allowed them to evaluate these theoretical explanations more accurately; see, for instance, Reilly (1995) as one of the earliest using this sort of data for the US. The RPED data is unique in that it is one of the only employer-employee matched data sets for developing countries and hence ideally suited for our purpose. Secondly, although clearly important, international comparisons, particularly between developing nations, of the employer size wage effect have generally been impaired by data differences across countries. The RPED data, however, provides comparable data for the countries that it covers.

Our paper is, of course, not the first to use the RPED data to examine the firm size wage effect in Africa. Previously, Velenchik (1997) explored various explanations for a wage premium for employees of large firms using the Zimbabwe data only, and found that a sizeable proportion remained unexplained. Mazumdar and Mazaheri (1999) examined the impact of labour productivity on the firm size effect for Ghana, Kenya, Zambia, and Zimbabwe using a somewhat different approach than is found in the previous literature, namely by simultaneously estimating wage and labour productivity determination equations under the assumption that the capital labour ratio does not affect an individual's wage directly. The authors find that although 
more of the employer size wage effect can be explained with their approach in terms of economies of scale and capital intensity effects, a large proportion still remains explicitly unaccounted for. In this paper, our purpose is to build on these two existing studies by using data for Cameroon, Ghana, Kenya, Zambia, and Zimbabwe to examine a number of alternative explanations for the firm size wage premium, but also to explicitly focus on cross-country comparisons, both within this group and relative to other developing and developed country studies.

The paper proceeds as follows. In the next section we briefly describe our data set. In Section III we present summary statistics relevant to examining the firm size wage effect. Subsequently, we systematically address and test for alternative explanations of the firm size wage premium in the aforementioned African countries as is possible with the data at hand. In Section IV we compare and discuss our results to those found for other developing and developed nations. Concluding remarks are provided in the last section.

\section{Section II: Data Set $^{3}$}

Data used in this study are drawn from three years, 1991-93, of the REPD survey for Cameroon, Ghana, Kenya, Zambia, and Zimbabwe. These data are part of a cross-country panel employer employee matched data set compiled by the REPD at the World Bank. In each of these five countries approximately 200 enterprises were surveyed across four sectors, namely food processing, wood and furniture, textiles, and metalworking, where these sectors comprise about eighty per cent of manufacturing employment. Additionally, within each firm around 10 workers were individually interviewed. The firms were sampled on the basis of size in order to generate a sample representative of the complete size distribution of firms in the manufacturing sectors of

\footnotetext{
${ }^{3}$ The data description is mostly take from Biggs et al (1998).
} 
these countries, whereas workers in the sample had an equal probability of being drawn. Apart from the matched information on firms and employees, the fact that that the data was collected in all countries at about the same time and with more or less identical questionnaires, makes the data particularly suited for cross-country comparisons.

The variables used in this study are those that have been kindly made available by the CSAE at Oxford or other variables generated from these available data. Additionally, we also used more detailed data available for Ghana, also made publicly available by CASE. Definitions of all variables used in this study are given in the Data Appendix. For all purposes in this paper we excluded all data derived from firms which have any state ownership, and all data on apprentices. One particular problem with the data is that, although firms can be matched over time, workers may be re-interviewed over the three years, but repeated observations of these cannot be identified in the available data. Even in the more detailed Ghana data set, it is only in the last available year that individuals are asked if they have been interviewed before. Clearly including several observations from the same individual in any sort of econometric estimation

should ideally take account of the potentially correlated error terms. As a rough check, we experimented matching observations between the second and third year for Ghana using information on an individual's gender, level of education and age. Using these two years we reestimated some of the regressions described below, both with controlling for correlation in the error terms of the matched observations and without, but this made little detectable difference.

\section{Section III: Descriptive Statistics}

In Table 1 we have calculated some summary statistics concerning our sample of firms for each country. Accordingly, firms in Zimbabwe are on average substantially larger, while those in Ghana are smaller, than in the other African countries. We also find that the mean 
hourly wage rate, converted to \$US at purchasing power parity, varies considerably across the countries' manufacturing sectors. For instance, Ghana also is characterized by the lowest average hourly wage rate, while firms in Kenya have an average hourly wage rate of more than four times that of firms in Ghana. It is clear from these averages that the country with the largest average firm size do not necessarily have also the highest average wage rate.

\section{[Table 1 here]}

In terms of our other descriptive variables we find that, on average, workers in Cameroon are in terms of purchasing power parity the most, while those in Zambia the least productive, followed closely by workers in Ghana. The incidence of at least some unionization does not differ substantially across countries, except in Zimbabwe where it is nearly double of all the others. However, once one takes into account the proportion of the labour force that is actually unionized, while unionization remains high in Zimbabwe, it is now Ghana for which unionization is highest. In terms of foreign ownership we find that Cameroon has the highest incidence of at least some foreign ownership amongst its manufacturing firms, standing on average at 31.8 per cent, while only 13 per cent of firms in the Zambian manufacturing sector in our sample are at least partially foreign owned. As indicated by the average capital to labour ratio, firms in Cameroon are on average most capital intensive, followed closely by those in Zimbabwe. In contrast, firms in Ghana manufacturing display on average at most 40 per cent of the capital intensity relative to the other four African countries.

Our summary statistics also suggest that the skill level (measured as the proportion of managers, supervisors, administrators, and technicians in a firm) is highest in firms in Cameroon and Kenya. The workforce of Kenyan manufacturing firms display on average the highest percentage of skill workers and of workers whose highest educational degree is at the secondary level, while their counterpart in Cameroon are characterized by the highest incidence of 
university degrees. The level of education amongst managers is also highest among firms in Cameroon. Clearly, however, the level of skill and education is lowest in terms of all these indicators among the employees at Ghanian manufacturing firms. Moreover, we discover that the level of supervision, measured as the number of supervisors and managers as a percentage of the workforce in a firm, is on average lowest in Ghana, while it is highest in Kenya.

\section{Section IV: The Basic Employer Size Wage Premium}

We have already noted that certainly from the firm level averages there appears to be no systematic relationship between employment size and the hourly wage rate across countries. Of course, as the standard deviations show, there is considerable variation within countries and hence we plotted the average wage rate in each firm against its size for each country in Figure 1. As can be seen, there clearly exists a positive relationship between the average hourly wage rate and the size of a firm. Moreover, in all five cases this relationship appears to be reasonably linear, although clearly the slopes differ somewhat.

In order to estimate the wage employer size relationship and derive the most rudimentary employer size wage premium, we simply regressed the logged values of the hourly wage rate on the logged values of firm employment for the given sample of workers for each country, only controlling for year specific effects with time dummies. The resultant coefficients of this exercise are given in the summary table, Table 2, whereas more detailed results are available in Appendix B in Table B1. As can be seen, the hourly wage rate of a worker is significantly positively related to employer size in all five countries, and these are roughly of similar magnitude. For example, a simple t-test shows that the coefficient for Cameroon, which is the highest, is only significantly different than that for Kenya.

[Table 2 here] 
Of course, in terms of assessing the impact of the employer size wage effect on the actual wage distribution one must take into account differences in the size distribution of firms across countries. We thus define the employer size wage premium, in a similar spirit to Brown and Medoff (1989), as twice the product of the coefficient on the log employment and the standard deviation of log employment (within each country). This can then simply be interpreted as the percentage wage premium that employees in a firm one standard deviation greater in size relative to the mean log employment receive relative to workers of firms one standard deviation below the mean log employment. The derived wage premium corresponding to the estimated coefficients for the aforementioned and all following regressions are reported in Table 3. As can be seen, clearly differences in the size distribution matter in terms of assessing the premium across countries. Using our proxy we find that the wage premium ranges from 57.1 per cent in Kenya to 72.3 per cent in Zimbabwe.

[Table 3 here]

\section{Section V: Empirical Analysis of Possible Explanations for an Employer Size Wage Premium}

We have thus far shown that large employers pay on average higher wages in all five of our African countries. Of course, workers and firms may differ across firm size and this needs to be controlled for. Moreover, there are a number of theories that could potentially explain why large employers may pay more. In order to investigate this we estimate a simple model of wage determination. Accordingly, an individual's wage is determined by: 
$\ln w_{i}=\alpha+\ln E_{i} \beta+X_{i} \partial+Z_{i} \lambda+\mu_{i}$

where $\operatorname{lnw}_{\mathrm{i}}$ is the logged value of the worker's hourly wage rate (in PPP $\$ U S$ ), $\ln E_{i}$ is the employment size of the firm in which the individual is employed, $X_{i}$ is a vector of worker specific observable characteristics, $Z_{i}$ is a vector of firm specific characteristics, and $\mu_{i}$ is worker specific error term. Our approach follows the one that is standard in the literature, namely to systematically include control variables for various potential explanations for the total, or subgroups thereof, country samples.

\section{Firm Characteristics}

Clearly there are many factors affecting the wage rate individuals receive. For example, in their classic study Krueger and Summers (1988) show that there are persistent differences across industries. Also, it has been shown that foreign firms, probably due to their greater use of technology, tend to pay higher wages than domestic firms, see for instance Aitken et al (1996). Finally, if labour markets are at least to some extent regional then the location of a firm may be an important determinant, in part due to differences in labour market tightness and differences in the cost of living. If these factors are unevenly distributed across firm size, ${ }^{4}$ then they may provide some explanation as to why larger firms pay higher wages.

\section{[Table 4 here]}

Indeed our data set allows us to identify whether firms are foreign owned, located in the capital city and which broad industry group within manufacturing they belong to. According to Table 4, which reports raw correlations of these variables with firm size we find that larger firms are more likely to be foreign owned, and in all countries except Kenya more likely to be located in the capital city, although the correlation coefficients for this latter aspect are fairly low. From these correlations it is also apparent that the sectoral location of firms by size are not necessarily 
similar across countries. The detailed results of including these firm characteristics as explanatory variables in (1) are given in Table B2 in the Appendix, while the coefficient on firm size is again included in our summary table, Table2. Not surprisingly we find that foreign firms and firms located in the capital city pay higher wages in all five countries. Additionally, the significance on at least some of the industry dummies in all countries is in line with the literature on inter-industry differentials. In terms of the coefficient on firm size we find that while it is reduced for all five countries, this fall is generally not large. As a matter of fact, a simple ttest reveals that the difference is insignificant in all cases. Nevertheless, as Table 3 shows, even small changes in the coefficient can significantly alter the effective wage premium, reducing it about ten percentage points in all five countries.

\section{Observable Worker Characteristics}

According to Becker's (1962) theory of human capital observed wage differences compensate for skills of workers, so that no worker should receive above-market wages given his/her skill levels and experience. We thus investigate whether observable, in the sense of our data, characteristics can explain the employer size wage effect in the five African countries. The ones available to us were the gender, tenure, age, education, and occupation of a worker. The results of including these variables are provided in Table B3 in the Appendix. These are reassuring in the sense of giving the expected, and significant, sign for most countries. Males tend to earn more in Ghana, Kenya, and Zimbabwe. Also older and more educated individuals are more likely to earn more. ${ }^{5} \quad$ The significance on the occupational dummies suggests that it is important to control for a worker's occupation. Most importantly, however, we find, as shown in Table 2, that including observable worker characteristics significantly reduces the coefficient on firm size, in the case of Cameroon and Zambia more than halving its size. Comparing the

\footnotetext{
${ }^{4}$ For instance, multinational corporations tend to be larger than domestic firms due to economies of scale.
} 
resultant coefficients across countries we find that Zimbabwe's still remains highest, followed by that of Ghana, while those of the other three countries are fairly close to each other. ${ }^{6}$ This has clear implications for the employer size wage premia as it is measured here, reducing it between 20 and 30 percentage points, as shown in Table 3. Overall, our results suggest that observable worker characteristics are important determinants of the hourly wage rate, and that this are unevenly distributed across firm size. Specifically, large firms tend to hire those workers with higher (observable) human capital. This finding lies in congruence with what has been found in other studies for both developing and developed countries - observable worker level characteristics are an important determinant in explaining firm size wage effect. ${ }^{7}$ For the remainder of this paper all regressions will thus include both firm and worker characteristics, and we refer to this as our base specification of (1).

\section{Unobserved Worker Skill Levels}

Of course, our limited number of worker level control variables are unlikely to be adequately proxying all skill differences across workers. In other words, differences in unobserved worker ability is likely also be an important determinant of the employer size wage effect. One of the earliest related theories in this regard is the capital-skill complementarity hypothesis by Hammermesh (1980), based on the model by Lucas (1978). Accordingly, the most skilled managers manage the largest firms, both in terms of the number of workers and the capital stock. If labour and capital are complements, then these managers will choose to hire the most skilled workers and hence have to pay these more. In order to assess this explanation we, as in

\footnotetext{
${ }^{5}$ Tenure is only significant for Cameroon and Zambia, although this is probably due to the high correlation with age.

${ }^{6}$ However, if we implement a simple ttest, under admittedly very strict assumptions, we find that only the coefficients form the Zimbabwe and Kenya are significantly different (at the ten per cent level).

${ }^{7}$ One should also note, that although we do not have as many personal controls as Velenchik (1997) for Zimbabwe, the size of our coefficient on firm sizes for this country is fairly similar, suggesting that the ones we do have capture most of the differences in average levels of observable human capital across firm sizes.
} 
Trotske (1997), include the capital-labour ratio in our base regression with firm and worker characteristics.

Examining the correlation of the capital-labour ratio with firm size first, as given in Table 3, we find that larger firms do tend to have higher capital intensity, although this correlation is not very strong for all countries. The coefficient associated with including this explanatory variable in (1) with worker and firm characteristics is, however, only significant for the Ghana, Kenya, and Zimbabwe data sets. However, as can seen be from Table 2, even for these countries it only slightly lowers the coefficient on firm sizes for Kenya and Zimbabwe and this change turns out to be statistically insignificant. Thus, failing to control for the capital intensity of a firm cannot account for the employer size wage premia observed in our five African countries. A similar result was found by Trotske (1997) and Reilly (1995) for the US.

Average Workers Skill Levels

Trotske (1997) also argues that the average skill level of the workforce in a firm may matter. Specifically, employers may find it more profitable to match workers with high skill levels with other workers with high skill levels. Consequently, if there are greater fixed costs associated with hiring and training the more skilled workers relative to the less skilled ones, then large firms would be more likely to match high skilled workers together. ${ }^{8}$ In order to investigate the possible role of this explanation in the firm size wage effect, Trotske (1997) includes measures of the average level of experience, education and occupation status as explanatory variables in his wage determination regression.

We similarly examine this possibility by using the proportion of the workers in a firm that completed secondary and university education, and the mean level of potential experience in a firm as proxies for the average level of skill in a firm. Our results given in the Appendix show

\footnotetext{
${ }^{8}$ See also Kremer (1993), Kremer and Maskin (19995), and Barron et al (1987).
} 
that in Cameroon, Ghana and Zimbabwe, the average skill level of the workforce, at least in terms of some of our proxies, significantly raises the hourly wage rate of workers, and hence that more skilled workers tend to work together. However, even in these countries, these factors do not significantly reduce the impact of firm size on payoff - as is apparent from Table 2 . In contrast, Trotske (1997) finds that the average skill level of the workforce has a small impact on the employer size wage premium in the US manufacturing sector.

\section{Rent Sharing}

Another possibility is that larger employers are more likely to be monopolistic and earn profits, and in order to elicit the optimum amount of effort from their employees are willing to share some of these rents. Traditionally, this has been examined by including measures of market power, however, these have not been found to have an effect on the employer size wage premium. ${ }^{9}$ Others, such as Velenchik (1997) for Zimbabwe and Trotske (1997) for the US, have also experimented with using value added or profits per employee, as a measure of rents, but again these did not have a significant impact. Given that we do not have access to measures of industry concentration, we similarly use the latter approach, by using value added per employee as a proxy for potential rent sharing. ${ }^{10}$ The simple raw correlation of this with employment shows that it is indeed positively related, except for Kenya. However, as can be seen from Table 2, including this variable in our base specification does not alter the coefficients on firm size in any noticeable matter, even though value added per employee is a significant positive determinant of the wage rate in Ghana and Zambia. ${ }^{11} 12$

\footnotetext{
${ }^{9}$ See, for instance, Weiss (1966), Mellow (1982), Brown and Medoff (1989), and Trotske (1997) for the US.

${ }^{10}$ We also experimented with profits per employee, but this did not change the results substantially.

${ }^{11}$ Detailed results are in the Appendix.

${ }^{12}$ Given that the firm level data refer to the previous year, we also tried in all our specifications using firm profits to also experiment with including firm profits from the year which corresponds to when the worker level information was collected. This did not significantly alter our results in any of our specifications.
} 
One must note particularly one problem with this approach. Dipak and Mazaheri (1999) argue that the value added (or profit) per employee in the wage equation, as a proxy for the potential of rent sharing, is likely to be an endogenous variable in that if an individual's wage reflects unmeasured productivity, this productivity is likely to increase a firm's labour productivity. ${ }^{13}$ To overcome this problem the authors estimate the wage equation and a firm's labour productivity equation simultaneously, and are thus able to distinguish economies of scale and capital intensity from other (unexplained) size effects on wages. ${ }^{14}$ They find that the economies of scale and capital intensity factors can account for by about 18 per cent, 11 per cent, and 26 per cent of the single equation size coefficient, for Ghana, Zambia, and Zimbabwe, respectively, but only 1 per cent in Kenya. Nevertheless even for the latter three countries a large size effect remains. ${ }^{15}$ In order to assess the possibility of endogeneity on aur results, we used information from the more detailed Ghana data to construct dummy variables indicating whether the firm is a price taker and whether the firm's main competitors were foreign as instruments. Using this in our $\mathrm{VAD} / \mathrm{L}$ specification for Ghana, as seen in Table 5, does not significantly alter the coefficient on the firm size variable.

\section{[Table 5 here]}

Another problem may be that even if a firm practices rent sharing not necessarily all workers share rents with the firm. Again, the more detailed Ghana data allows us to examine the potential effect of this problem by providing worker level information on whether the worker's

\footnotetext{
13 This may particularly problematic for small firms in which an individual's unmeasured productivity is likely to influence the overall labour productivity in the firm than in large firms.

${ }^{14}$ The authors argue that this unexplained size effect is due to organisational differences between large and small firms. One problem with their method of estimating the firm size wage effect is that they implicitly assume that the capital labour ration only affects the labour productivity of the firm (for example, through capital market segmentation), but does not affect an individual's wage. Clearly, this may not be the case if the capital intensity increases a worker's productivity and hence his wage rate, and some evidence points to the possibility - see Oi and Idson (1999) for a discussion of this.

${ }^{15}$ Moreover, it still remains larger than what has been found in comparable studies of the industrialis ed world.
} 
wage is a share of sales and whether the worker received a merit/production bonus. ${ }^{16} \mathrm{We}$ constructed dummy variables for these and then interacted them with VAD/L. Our results of including this in our wage equation, instrumented, as above, are given in Table4. As can be seen, however, this did not significantly alter the degree of the employer size wage effect.

Firm Age

Brown and Medoff (1989) propose that employers that treat their employers well, by paying them relatively more, are more likely to grow and survive, and that this could also produce the employers size wage effect. This is related to the efficiency wage explanation in the sense that in a strictly competitive market firms with higher wages would incur higher costs, and would only survive if their workers, in response to the higher wages, were also more productive.

Examining the raw correlation of firm age with firm size we indeed find that these are positively correlated. In order to investigate whether this may be underlying the firm size wage premium in our five African countries, we included a firm's age as an additional explanatory, although, unfortunately, this was not available to us for Zambia. However, it turns out, as can be seen in Table B5 in the Appendix, this variable has a significant impact on the hourly wage only for Ghana, but is not of the expected sign. ${ }^{17}$ At any rate, in no case does the inclusion significantly alter the coefficient on firm size as revealed in Table 2. The lack of impact of firm age on the wage premia of larger firms is in line with the findings of Trotske (1997) for the US.

\section{Union Avoidance}

There is some evidence in the industrialized world that some larger firms may pay higher wages in order to avoid unionism among their workers. ${ }^{18}$ Velenchik (1997) examines this for

\footnotetext{
${ }^{16}$ Raw correlations between these and employment size indicated a very low negative relationship.

17 A lack of a positive correlation between firm age and wages was previously found by Brown and Medoff (1995) and is also in conjuction with the results by Trotske (1997).

${ }^{18}$ For instance, for the US Freeman and Medoff (1984) documented that the wage differential between unionised and non-unionised members is much smaller in larger establishments.
} 
Zimbabwe by including a control for whether a firm is unionized in the wage determination equation and finds that this reduces the employer size wage effect between small and medium sized firms, but not for other parts of the wage distribution. We similarly examine the importance of union avoidance for all five African countries, but rather than categorizing firms as unionized or non-unionised use the percentage of the workforce in each firm as in indicator of the presence of unionization, given that this measure can capture differences in union intensity among unionized firms. ${ }^{19}$ Our results, details of which are again provided in the Appendix, show that union density in a firm does not have a significant impact on an individual's wage for any of the five countries.

Another way of measuring the impact of this is to examine the employer size wage effect for unionized and non-unionised workers separately. If union avoidance is, ceteris paribus, an important factor in the employer size wage effect then one should expect that there is only a wage premia in larger firms for non-unionised workers only. Unfortunately additional data on the union status of workers is available to us for the 1992 and 1993 observations for Ghana only. Nevertheless, we ran our base specification with worker and firm characteristics for these two samples separately using the Ghana data, and found that the coefficient on firm size for the nonunionised sample on firm size coefficient was 0.186 , whereas the one for the sample of union workers turned out to be 0.101 . While the larger coefficient for the non-unionised sample does provide some suggestive evidence of the existence of union avoidance among larger firms, the fact that unionized workers are also still subject to a large firm size wage premia suggests that this explanation can at best only explain a small proportion of this phenomena.

Manager Skill Levels

\footnotetext{
19 The raw correlation, however, shows that larger firms in our five African countries are more likely to be unionised in all five countries.
} 
A related explanation for the firm size wage effect to that offered by Hammermesh (1980) is that by Oi's (1983) model. In this framework the most skilled managers work in the largest firms, but must divide their time between monitoring workers and managing the firm. It is also assumed that the more skilled managers are assumed to be better at managing the firm rather than monitoring workers, while the more skilled workers require less monitoring. Hence, one would expect that the more skilled managers hire the more skilled workers, and a wage size premium may result from not controlling for the skill level of managers in a firm.

As in Trotske (1997) we included in our base specification of (1) proxies of managerial ability in regressions on non-managerial worker samples for the African countries. ${ }^{20}$ Specifically, we controlled for the proportion of managers in a firm whose highest level of education was secondary secondary and the proportion of which whose highest level of education was at the university level. Doing this we discover, as reported in the Appendix, that managerial ability only has a significant positive impact on wages in Cameroon and Ghana; for the former, the proportion of managers with highest level of education at the university level, and for the latter the proportion with the highest level of education at either the tertiary or secondary level were important determinants of the wage rate of non-managerial workers.

To asses whether the inclusion of managerial ability controls has had an impact on the employer size wage effect in these countries, we estimated our base specification with worker and firm level characteristics for non-managerial workers only, the coefficients of which are given in Table 2 and more detailed results in the Appendix. As can be seen, the coefficient on the firm size variable is substantially smaller relative to the total sample for all countries, implying a wage premium for working in a large firm ranging between 19 and 35 per cent for this subgroup in Africa. Inclusion of the managerial ability controls only has a noticeable effect in

\footnotetext{
${ }^{20}$ We consider both managers and supervisors as part of the managerial category.
} 
those countries in which these turned out to be significant explanatory variables of the hourly wage rate - Cameroon and Ghana. However, although a simple ttest does not suggest significant differences in the coefficient even for these, nevertheless in the case of Ghana the reduction in the coefficient causes a nearly ten percentage point drop in the firm size wage premium. In contrast, Trotske (1997) finds no relationship between wages and managerial ability, and that the inclusion of the latter does not alter the firm size wage effect or premium.

\section{Monitoring}

Firms may also pay higher wages to workers to entice them not to shirk on the job. If the cost of shirking is more expensive in larger firms, or alternatively the cost of monitoring is higher in larger firms, than one should expect larger firms to pay higher wages, in this context known as efficiency wages, and engage in less monitoring than smaller firms. ${ }^{21}$ If this were the cae in our five African countries, than controlling for monitoring should be able to account for the employer size wage effect.

Using information on the distribution of workers by occupational group in a firm, we calculated the ratio of supervisors and managers relative to the total workforce for each firm. The raw correlation of this with firm size is indeed negative for all countries except for Ghana. However, including this variable in our base specification of (1) for our sample of nonmanagerial workers does not significantly alter the firm size coefficient, as reported in , moreover, as can be seen in the Table in the appendix, the rate of monitoring is insignificant for all country samples. Our results may not be suprising given that Velenchik (1997) argues that, since threat of dismissal is integral to the shirking argument, with the difficulty associated in dismissing permanent workers in sub-saharan African the efficiency wage argument outlined above is not likely to have had an effect on the firm size wage distribution. In Zimbabwe, for

\footnotetext{
${ }^{21}$ See Velenchik (1997).
} 
example, employers instead maintain a stock of casual workers under fixed (but often renewed) term contracts, and statistics show that the proportion of these in the workforce rises with employment size. One should also note that while in the US (see Trotske, 1999) a proxy for monitoring intensity turned out to be significant and of the expected sign, its inclusion did not significantly alter the employer size wage premium. In their simultaneous equations model of the firm size wage effect, Mazumdar and Mazaheri (1999) also use the wage premium, calculated as the residual wage from an earnings regression similar to (1), as a proxy for efficiency wages. They find that only in the case of Kenya does it significantly increase labour productivity, hence suggesting that for this country efficiency wages might be important for the remainder employer size wage effect. Again, however, the remaining employer size wage effect remains large.

One possibility is that our results are biased given that one could argue that the rate of monitoring is simultaneously determined with wages as firms are likely to choose both the wages they offer and the degree of monitoring at the same time. One way of dealing with this is to appropriately instrument the rate of supervision. For Ghana, for which we have more detailed data, there is information on whether the firm is affected by hiring and firing/layoff restrictions legislation and we appropriately constructed a zero-one type dummy variable as to whether a firm was subject to any restrictions and used this as an instrument for the degree of monitoring. However, this did not significantly alter the coefficient on employment size (0.123) and, although the rate of monitoring was now significant for Ghana, it was unexpectedly positive. Hence, the possible endogeneity of our monitoring proxy is unlikely to alter our conclusion that this form of efficiency wages cannot serve as an adequate explanation for the employer size wage effect.

\section{Worker Turnover}

As noted by Oi (1999) worker turnover rates tend to be inversely related to firm size. One possible reason for this is that large firms provide more on the job training and/or that hiring is 
more expensive for larger firms in general. Given these larger overhead costs it may thus be in the interest of larger firms to reduce labour turnover relatively more by offering higher wages. Using data that is solely available on Ghana for worker turnover, we calculated the degree of excess turnover, i.e., the worker turnover in excess of net employment changes, for each firm over the three years in order to include it in our wage equation. ${ }^{22}$ Given that excess turnover may to some extent be simultaneously determined as firms set wages according to desired turnover rates, we instrumented this variable with a dummy indicating whether the firm was subjected to hiring and firing restrictions. The subsequent coefficient on our excess turnover rate variable turned out to be, contrary to expectations, positive and significant and did not significantly alter the size of the employer coefficient (0.133), indicating that higher wages in larger firms are not likely to be significantly associated with reducing costs associated with worker turnover. ${ }^{23}$

\section{Benefits}

Similar to the union avoidance argument one could argue (see Brown and Medoff, 1989), that larger firms may pay higher wages in order to avoid paying benefits to their workers. Using our detailed data for Ghana we were able to derive information on whether firms provided health care benefits for their workers and/or their families, over-time pay, paid leave, paid public holidays, and/or pensions funds, and included set of dummies indicating the provision of these in the regression for Ghana. The sample for which there are non-missing observations on these benefit dummies produced a firm size coefficient of 0.105 . Including the set of dummy variables reduced this coefficient to 0.086 , suggesting a small, but insignificant, reduction in the employer size wage effect. Moreover, those dummy variables that were significant, namely the provision

\footnotetext{
${ }^{22}$ Excess turnover was, as in other countries, negatively correlated with firm size.

${ }^{23}$ We also experimented with including a dummy for whether the worker received on the job training, but this variable was not significant and did not alter the employer size coefficient.
} 
of health care benefits and over-time pay, had a positive effect on wages, suggesting that higher paid jobs additionally provide these benefits.

\section{Other Explanations}

Of course our data did not allow us to examine all potential explanations that have been put forth and examined in the literature thus far. Amongst the ones for which we do not have sufficient data for each country to address, are, for example, those that posit that there are differences in terms of working conditions, the importance of filling vacancies, and the greater incidence of job-specific training across firm size. However, it must be noted, for those studies in which data did allow these aspects to be examined, they were unable to explain the employer size wage effect in any significant way. ${ }^{24}$

We also have not addressed institutional explanations, other than union avoidance, that may have an important role to play in explaining the wage size premium. For example, minimum wage legislation could conceivable affect the premium if compliance differs across firm sizes. However, Velenchik (1997), Schaeffer (1998), and Marcelle and Strobl(1998) have argued, with the support from either direct or indirect evidence, that the minimum wage legislation has had little impact on the firm size wage effect in Zimbabwe, Peru, or Trinidad and Tobago, respectively. Moreover, in their comparative study of four Nordic countries with the US, Albaek et al (1996) show, that despite large differences in the instutional arrangements of the Nordic and US labour markets, the employer size wage effect was fairly similar and thus conclude that labour market institutions are unlikely to explain the size of the employer size wage premium.

There are also other methods that take account for such problems as sample selection bias or unobserved factors that are correlated with employer size that we were unable to implement. 
However, as the review by Oi and Idson (1999) of the literature demonstrates these were not able to solve the puzzle in the US, and studies by Schaeffer (1998) and Marcelle and Strobl (2001) suggest a similar conclusion for developing countries.

\section{Section VI: Comparison to Other Developing and Developed Countries}

Our results thus far not only suggest that existing theories are not able to empirically account for the wage premium associated with larger employers, but that the effect does not differ greatly across our five African countries. Even when we include all our significant control variables for each country, as shown in Table 2, the coefficients remain largely unchanged relative to our base specification and hence fairly similar across countries. As a matter of fact, a simple t-test reveals that the coefficients do not differ significantly between any of these. We thus now proceed to compare our results to those of other developing nations and the industrialized world.

\section{Comparison to other Developing Countries}

Direct comparisons of the employer size wage effect within the developing world are difficult given the range of data and the employer size variable used. Using the African data set we constructed similar firm size dummies as used in Schaeffer (1998) for Peru and display the coefficients of these using firm and worker characteristics, in conjunction with Schaeffer's results, in Table 6, although it must be kept in mind that the African data is for manufacturing only and only covers formal sector employees. Moreover, the choice of firm size dummies is in a sense a bit arbitrary, and a different set could conceivable result in different conclusion. Some argument could be made that one might ideally like to control for the different size distribution of firms in countries when selecting the firm size categories, however, we are unable to do so.

${ }^{24}$ For a study of the impact of working conditions see, for instance, Schmidt and Zimmermann (1991). Velenchik 


\section{[Table 6]}

As can be seen, relative to micro firms (1-10 employees), small firms (11-50) only pay significantly higher wages in Ghana, Kenya, and Zimbabwe, although this may be because of the lack of coverage of the informal sector in the African data sets. We find that the medium sized firm (51-100) wage effect, again relative to micro firms, is noticeable higher in Ghana and Zimbabwe, but lower in Zambia. The largest of firms (101+ employees) pay higher wages than in Peru relative to micro level firms in Cameroon, Ghana, and Zimbabwe, while in the remaining two African countries they are roughly similar. Perhaps the most striking feature is that the firm size wage effect in Zimbabwe is always considerably greater than in Peru. This occurs despite not including the informal sector, which one would expect to magnify the employer size wage effect even further. ${ }^{25}$

We also had access to data used in Marcelle and Strobl (2001) for Trinidad and Tobago, and with this constructed comparable estimates for the employer size wage effect for firms with at least ten employees. ${ }^{26}$ Accordingly, the coefficient on this zero-one type employer size variable for Trinidad and Tobago, 0.469, was larger than those of Cameroon, Ghana, Kenya, and Zambia, which were $0.191,0.314,0.249$, and 0.112 , but was smaller than that of Zimbabwe, which was 0.618. One should note, however, that, as in the case for the Peruvian data, the Trinidad and Tobago data also includes informal sector employees, and hence one would expect the coefficients for the African countries to underestimate the true firm size wave effect.

\section{Comparison to Developed Countries}

(1997) does not find any evidence of quit rates differing across employers.

25 This point was already made by Velenchik (1997).

26 This choice of firm size categories was due to data restrictions in the Trinidad and Tobago data set. We furthermore reduced the Trinidad and Tobago sample to employees in the manufacturing sector and only included control variables that were common to both data sets. Detailed results are available from the authors. 
Although the number of studies on developing countries is marginal compared to what is available for the developed world, they thus far strongly indicate that the employer size wage effect is substantially larger in the developing world. For instance, Schaeffer (1998) uses Peruvian data to construct a firm sze variable similar to ones that can be constructed for the US using the CPS and found that the wage effect is substantially larger in Peru, particularly for workers employed in very small establishments - these are also given in Table 6. As can be seen, the employer size wage effect appears to higher in the African countries relative to the US particularly for higher firm size categories, although it must be pointed out that the exclusion of the informal sector is likely to underestimate the firm size wage effect for our five African nations. $^{27}$ Other studies similarly suggest that in relative terms the employer size wage effect is large in developing labour markets; see, for instance, Little et al (1987) for evidence for Bombay and Malaysia.

In their sudy of Nordic countries Albaek et al (1998) use, as was done here, a continuous measure of firm size which allows a direct comparison to our results, except for the fact their data sets cover the entire labour markets rather than just the manufacturing sector. The authors find in their specification using worker characteristics ${ }^{28}$ and industry and regional dummies the coefficient on firm size to be $0.025,0.020,0.025$, and 0.021 for Denmark, Finland, Norway, and Sweden, respectively. These are, of course, considerably smaller than our comparable ones for the five African countries in Table 4 and hence add further credibility to the claim that the employer size wage effect is smaller in the industrialized world. The study that is probably the most directly comparable to the one undertaken here is that by Trotske (1999), who similarly uses a employer-employee matched data set and a continuous measure of firm size for the US

\footnotetext{
27 For instance, comparing the Peruvian data, which includes informal sector employees, although there is clearly a large effect in Peru, this effect does not seem to magnify as one moves up firm size categories.
} 
manufacturing sector. In his base specification with worker and firm control variables, he finds that the coefficient on firm size is 0.033 , implying a wage premium of 15 per cent. Again the discovered employer size wage effect is considerably smaller than the ones we find here.

Perhaps one finding by Trotske (1997), which was already earlier documented by Brown and Medoff (1989), which may lend some insight into why the employer size wage effect is larger in developing countries is that in the US the employer size wage effect is slightly smaller for white collar than for blue collar workers. For instance for white collar workers excluding managers he finds a coefficient on the firm size variable of 0.021 compared to that of 0.032 for blue collar workers. $^{29}$ In an earlier study, Doms et al (1997) noticed that firm size had the same impact across skill categories, whereas Oi and Idson (1999) find a decreasing effect with rising skill level, both for the US. Although this aspect has not been examined for other developed nations, we suspect, given that the employer size effect does not appear to differ dramatically, that a similar pattern, either slightly smaller or similar firm size wage effect for higher skill levels and white collar workers, would be found for these as well. In contrast, for those developing country studies which have estimated the employer size wage effect separately for white and blue collar workers, namely Mazumdar (1984) for Bombay, Mazumdar (1981) for Malaysia, as well as Schaeffer (1998) and Marcelle and Strobl (2001), blue collar workers have been found to be subject to a larger effect. Also, Mazumdar (1994), using RPED data, noticed a similar trend for Kenya, Zambia, Zimbabwe, and Cameroon. For completeness sake, we similarly divided the data of the five African countries into these sub-groups and estimated the firm size wage effect for these separately, as given in Table 2. As can be seen, Ghana, like the other four African

\footnotetext{
${ }^{28}$ The worker characteristics are schooling, experience, experience squared, seniority, gender and occupational dummies.

${ }^{29}$ The coefficient on a sample of managers only was 0.004 .
} 
countries, is no outlier to this trend, in all cases the coefficient is higher for blue collar workers. ${ }^{30}$ As in Trotske (1997), we also estimated the firm size wage effect separately for those white collar workers that are supervisor and managers, and found this to be higher than for the remaining white collar workers. ${ }^{31}$ In contrast, Trotske (1997) finds the effect to be even smaller for these.

Velenchik (1995), who similarly found a larger effect for her earlier study of Zimbabwe using the same data source, suggests a number of possible reasons. Firstly, if unfilled positions are more costly in larger firms because they have higher stocks of potentially idle capital, and the labour market for white collars is relatively more tight, then the firm size wage premium would, ceteris paribus, be higher for white collar workers. A similar effect would be expected if the acquisition of firm specific human capital is more important for white collar workers in general, but specifically in larger firms. While hypothetically both of these reasons seem plausible explanations, it is not clear why this effect should be less important in developed countries like the US. Velenchik (1995) also suggests that the difference across these two broad occupational groups could be because monitoring cots are higher for white collar workers. Again, there appears to be little reason why this should be different in the developed world. Nevertheless, we re-estimated the effect of monitoring for white collar workers as was done earlier for all nonsupervisory employees. This changed little in terms of the employer size wage effect for white collar workers, and, in fact, the monitoring proxy was only significant for Zimbabwe.

Perhaps the most promising explanation for the occupational difference in the firm size wage effect derives from results found by Tan and Batra (1997). Specifically, the authors examine the impact of technology on the firm size wage relationship for skilled and unskilled workers in Columbia, Mexico and Taiwan. They find that the employer size wage effect is

\footnotetext{
${ }^{30}$ We also used total worker samples and included a white collar dummy variable and an interaction term of this and firm size. In all cases the interaction term was positive and significant, except in the case of Ghana were it is marginally insignificant.
} 
higher for skilled workers than for unskilled workers in technology investing firms only. They consequently argue that the likely explanation for this is that technological change was skillbiased and that larger firms are more likely to be technology intensive.

In order to determine whether a similar explanation is likely for Sub-Saharan Africa, we classified employers in Ghana, for which this data was available to us, into technology intensive and non-intensive firms. Specifically, we classified firms as technology intensive if they were actively conducting $\mathrm{R} \& \mathrm{D}$, foreign firms, exporters, or invested in new capital equipment in the last three years. ${ }^{32}$ We found that our technology intensive firms have an average size of 64, while the non-intensive firms, have an average of 28 employees, thus providing support for the assertion that larger firms are more technology intensive.

Using this classification we ran separate regressions for these groups on the determinants of the hourly wage rate using our firm and worker characteristics ${ }^{33}$ but also including a white collar dummy and its interaction with firm size. The results for this exercise are given in Table 7. As can be seen, the white collar dummy variable and its interaction with firm size are insignificant for non-intensive sample. The coefficient on the firm size variable, 0.266, is significant, and considerably larger than what was found for the overall sample. In contrast, for employees working in technologically intensive firms, the coefficient on employer size wage effect is less than a fifth of this, standing at 0.053. Moreover, the coefficient on the interaction term of the white collar worker dummy with employment, 0.063, is significant, and suggests that the 'white collar worker effect' more than doubles the firm size wage effect in technologically intensive firms. Our results of this exercise thus indicate that there are only differences in the

\footnotetext{
${ }^{31}$ Results are available from the authors.

32 Betra and Tan (1997) classified firms as technology intensive if they exported, conducted R\%D, or provided training to their employees.

33 The only variables we excluded were foreign ownership and our occupational dummies given that these were part of our classification of workers working for technological investor/non-investors and being white/blue collar workers. Including these makes little difference in our results.
} 
employer size wage effect between blue and white collar workers in firms that are technology intensive, thus providing support for a skill biased technical change explanation of occupational differences. For the case of Ghana, the white collar effect more than doubles the existing firm size wage effect in technology intensive firms - without it the firms size wage effect would be, for instance, much closer to that found for developed countries. Moreover, our results, given the relative total employer size wage effect across these two groups of firms suggests, that much of the large employer size wage effect in developing countries may be due to the wage structure of low technology firms.

\section{[Table 7 here]}

There are a number of ways in which this finding could account for the broad occupational differences in the employer size wage effect in developing countries relative to the US. For one, larger firms in the US may not be more technology intensive than smaller firms and/or technology in the US is not skill biased. However, indirect empirical evidence with regard to these matters does not provide strong support for either of the first two possibilities. For example, with regard to technological intensity, Dunne and Schmitz (1995) find that in the US larger firms are more likely to use advanced technology. In terms of skill-biased technological change, Katz and Murphy (1992) and Davis and Haltiwanger (1991) discover that skill-biased technological change played a major role in wage inequality between skilled and unskilled workers. On the other hand, Trotske (1997) does find that including total new investment in computers as a control variable does not significantly alter the employer size wage effect, although it must be pointed out that he does not carry out this particular exercise separately for white and blue collar workers. More plausibly it may be that the difference in technology use across firm size is not that large in the industrialized world. Also, it may be that at higher 
absolute levels of technology, which they are likely to be in developed countries such as the US, such a white collar effect is simply not important anymore.

\section{Section VII: Conclusion}

In this paper we examined the wage premium associated with working in a large firm using comparable data for five African countries. Specifically, we evaluated a number of theoretical explanations that have been put forth to explain this phenomena. Like in almost all studies of the employer size wage effect, almost all fall short of explaining a significant proportion of the employer size wage premium. Only observable worker characteristics can explain a large proportion, suggesting that those with higher observable human capital work in larger firms. Nevertheless, a large unexplained proportion remains, as has been found elsewhere.

Perhaps more interestingly, we find that the unexplained remainder of the employer size wage effect does not appear to be significantly different across the five countries, so that differences in the actual premium are due to differences in the firm size distribution. Similar lack of differences in the employer size wage effect have also been found in the industrialized world, even between countries that have markedly different labour market institutions. However, comparisons of the developed to the developing world have consistently shown that the effect is noticeably larger in the former, and our study is no exception to this stylized fact.

One very noteworthy aspect unearthed in our study, and that appears to be characteristic of other developing nations as well, that may go some way in explaining the differences across levels of development is that, in contrast to industrialized nations, unskilled or blue collar workers suffer from a lower wage premium than the skilled or white collar workers. Evidence from one of the countries for which richer data was available, in conjunction with results from other studies, suggests that this may be because larger firms are more likely to embody new 
technologies and the technical change associated with this has been skill biased. Possible reasons why a similar trend is not apparent in developed nations, at least not in the US, may be that there is a wider dispersion of technology in developing countries, that at lower levels of technology this effect may be more important, and/or that skill biased technical change has not been different across firm sizes in the industrialized world. Clearly, however, further research on this issue is required. 


\section{References}

Albaek, K., Arai, M., Asplund, R., Barth, E. and Madsen, E. (1998). "Measuring Wage Effects of Plant Size", Labour Economics, 5, pp. 425-448.

Barron, J., Black, A.D., and Loewenstein, M.A. (1987). "Employer Size: The Implications for Search, Training, Capital Investment, Starting Wages, and Wage Growth", Journal of Labour Economics, 5, pp. 76-89.

Becker, G. (1962). "Investment in Human Capital: a Theoretical Analysis", Journal of Political Economy, 70, pp. 9-49.

Biggs, T., Ramachandran, V., and Shah, M.K. (1998). "The Determinants of Enterprise Growth in Sub-Saharan Africa: Evidence from the Regional Programme on Enterprise Development", World Bank RPED Paper No. 103.

Brown, C. and Medoff, J. (1989). "The Employer Size Wage Effect", Journal of Political Economy, 97, pp. 1027-1059.

Davis, S.J. and Haltiwanger, J. (1991). "Wage Dispersion between and within U.S. Manufacturing Plants, 1963-86”, NBER Working Paper Series, No. 3722.

Doms, M., Dunne, T., and Trotske, K.R. (1997). "Workers, Wages and Technology", Quarterly Journal of Economics, 112, pp. 253-290.

Evans, D.S. and Leighton, L.S. (1989). “Why Do Smaller Firms Pay Less?”, Journal of Human Resources, 24, pp. 299-318.

Hammermesh, D.S. (1980). "Commentary”, in The Economics of Firm Size, Market Structure and Social Performance, ed. Siegfried, J.J., Washington, DC: Federal Trade Commission.

Katz, L.F. and Murphy, K.M. (1992). "Change in Relative Wages, 1963-1987: Supply and Demand Factors”, Quarterly Journal of Economics, 107, pp. 35-78.

Kremer, M. (1993). “The O-Ring Theory of Economic Development", The Quarterly Journal of Economics, 108, pp. 551-575.

Kremer, M. and Maskin, E. (1995). “Segregation by Skill and the Rise in Inequality”, mimeo.

Krueger, A., and Summers, S. (1988). "Efficiency Wages and the Inter-Industry Wage Structure", Econometrica, 56, pp. 259-293.

Little, I.M.D., Mazumdar, D., and Page, J.M. (1987). Small Manufacturing Enterprises: A Comparative Study of India and Other Economies, Oxford University Press: New York.

Lucas, R.E. (1978). "On the Size Distribution of Business Firms", The Bell Journal of Economics, 9, pp. 508-523. 
Marcelle, M. and Strobl, E. (2001). "Do Smaller Firms Pay Less in the Caribbean? The Case of Trinidad and Tobago", mimeo.

Mazumdar, D. (1981). The Urban Labour Market and Income Distribution: A Case Study of Malaysia, Oxford: Oxford University Press.

Mazumdar, D. (1983). "The Rural-Urban Wage Gap, Migration and the Working of Urban Labour Markets: An Interpretation Based on a Study of the Workers in Bombay City", Indian Economic Review, 18, pp. 169-198.

Mazumdar, D. (1994). "The Structure of Wages in Africa”, World Bank RPED Paper No. 33.

Mazumdar, D. and Mazaheri, A. (1999). "The Structure of Labour Markets in Africa", World Bank RPED Paper No. 106.

Mellow, W. (1982). "Employer Size and Wages", Review of Economics and Statistics, 64, pp. 495-501.

Moore, H.L. (1911). Laws of Wages: An Essay in Statistical Economics, New York: Augustus M. Kelly.

Oi, W.Y. (1983). "The Fixed Employment Costs of Specialised Labour", in The Measurement of Labour Costs, ed. Triplett, J.E., Chicago: University of Chicago Press.

Oi, W.Y.., and Idson, T. (1999). "Firm Size and Wages", in Handbook of Labor Economics, eds. Ashenfelter, O. and Card, D., Amsterdam, North-Holland.

Reilly, K.T. (1995). „Human Capital and Information“, Journal of Human Resources, 30, pp. 118.

Schanffer, J.A. (1998). "Premiums to employment in larger establishments: Evidence from Peru", Journal of Development Economics, 55, pp. 81-113.

Schmidt, C.M. and Zimmermann, K.F. (1991). „Work Characteristics, Firm Size and Wages”, The Review of Economics and Statistics, 73, pp. 705-710.

Stiglitz, J.E. (1974). "Alternative Theories of Wage Determination and Unemployment in LDCs: the Labor Turnover Model”, Quarterly Journal of Economics, 88, pp. 194-227.

Tan, H. and Batra, G. (1997). "Technology and Firm Size-Wage Differentials in Columbia, Mexico, and Taiwan (China)", World Bank Economic Review, 11, pp. 59-83.

Trotske, K.R. (1997). „Evidence on the Employer Size-Wage Premium from WorkerEstablishment Matched Data“, mimeo.

Valenchik, A.D. (1995). "Government Intervention, Efficiency Wages and the Employer-Size Wage Effect”, World Bank RPED Paper No. . 
Valenchik, A.D. (1997). “Government Intervention, Efficiency Wages and the Employer-Size Wage Effect”, Journal of Development Economics, 53, pp. 305-338.

Weiss, L. (1966). “Concentration and Labour Earnings", American Economic Review, 56, pp. 96-117.

Winter-Ebmer, R. and Zweimuller, J. (1999). "Firm-Size Wage Differentials in Switzerland:

Evidence from Job-Changers", American Economic Review, Papers and Proceedings, 89, pp. 8993. 
Figure 1: Employer Size and Wage Relationship (logged values)
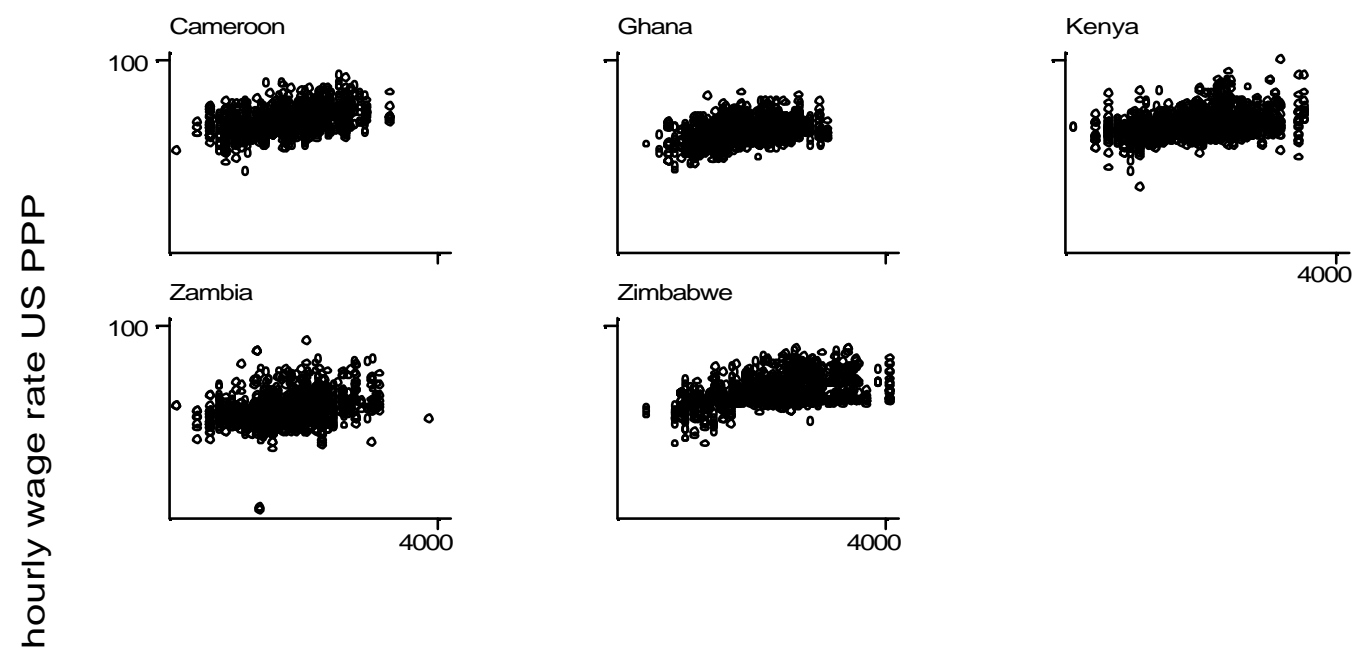

number of employees 
Table 1: Summary Characteristics - All Firms

\begin{tabular}{lccccc}
\hline & Cameroon & Ghana & Kenya & Zambia & Zimbabwe \\
\hline Size (mean) & 112 & 52 & 97 & 80 & 350 \\
Size (st.dev.) & 395 & 80 & 247 & 181 & 671 \\
Hourly Wage (mean) & 3.66 & 0.89 & 4.81 & 1.85 & 4.31 \\
Hourly Wage (st. dev.) & 1.91 & 0.55 & 2.36 & 1.36 & 1.73 \\
Age & 10 & 14 & 18 & N/A & 25 \\
VAD/L & 29848 & 8327 & 18091 & 6308 & 14959 \\
Union (\% Firms) & 38.0 & 31.9 & 47.5 & 43.3 & 78.9 \\
Union (\% Emp.) & 28.1 & 69.9 & 34.6 & 34.8 & 49.6 \\
Foreign & 31.8 & 19.7 & 16.5 & 13 & 25.6 \\
K/L & 26884 & 7786 & 19021 & 17070 & 23446 \\
\% Skill & 51.2 & 15.0 & 88.7 & 81.2 & 73.9 \\
\% Univ. & 15.4 & 1.5 & 10.7 & 10.0 & 8.9 \\
\% Sec. & 55.8 & 24.5 & 59.1 & 52.1 & 41.9 \\
\% Sec. Man. & 50.7 & 16.3 & 39.7 & 42.4 & 34.3 \\
\% Univ. Man. & 19.5 & 3.4 & 4.5 & 8.2 & 4.4 \\
\% Supvis. & 26.1 & 7.5 & 64.5 & 58.5 & 54.2 \\
\hline
\end{tabular}

Table 2: Summary of Employer Size Wage Effect

\begin{tabular}{llccccc}
\hline Sample & Controls & Cameroon & Ghana & Kenya & Zambia & Zimbabwe \\
\hline All workers & None & 0.277 & 0.250 & 0.185 & 0.243 & 0.234 \\
All workers & F & 0.234 & 0.215 & 0.157 & 0.197 & 0.203 \\
All workers & F,W & 0.098 & 0.114 & 0.090 & 0.096 & 0.138 \\
All workers & F,W,S & 0.100 & 0.105 & 0.095 & 0.098 & 0.136 \\
All workers & F,W,K & 0.099 & 0.109 & 0.088 & 0.096 & 0.125 \\
All workers & F,W,P & 0.101 & 0.100 & 0.092 & 0.085 & 0.137 \\
All workers & F,W,A & 0.102 & 0.130 & 0.089 & N/A & 0.126 \\
All workers & F,W,U & 0.099 & 0.084 & 0.095 & 0.093 & 0.142 \\
All workers & F,W, significant & 0.097 & 0.116 & 0.088 & 0.081 & 0.127 \\
White C. & F,W & 0.117 & 0.162 & 0.095 & 0.122 & 0.247 \\
Blue C. & F,W & 0.072 & 0.086 & 0.083 & 0.074 & 0.098 \\
Non-Man. & F,W, & 0.084 & 0.111 & 0.087 & 0.089 & 0.119 \\
Non-Man. & F,W,E & 0.079 & 0.068 & 0.087 & 0.088 & 0.125 \\
Non-Man. & F,W,M & 0.087 & 0.111 & 0.093 & 0.118 & 0.111 \\
\hline
\end{tabular}

Notes: 1. Control Variables: $\mathrm{W}$ - worker characteristics; F - firm characteristics; $\mathrm{S}$ - skill level of firm; $\mathrm{K}$ capital/labour ratio; $\mathrm{P}$ - firm profit; $\mathrm{E}$ - educational level of Managers; $\mathrm{M}$ - percentage of managers;

2. All regressions include year dummies.

3. All coefficients are statistically significant at at least the five per cent level. 
Table 3: Summary of Wage Premium

\begin{tabular}{llccccc}
\hline Sample & Controls & Cameroon & Ghana & Kenya & Zambia & Zimbabwe \\
\hline All workers & None & 66.8 & 57.3 & 57.1 & 63.8 & 72.3 \\
All workers & F & 56.5 & 49.2 & 48.4 & 51.7 & 62.7 \\
All workers & F,W & 23.6 & 26.1 & 27.8 & 25.2 & 42.6 \\
All workers & F,W,S & 24.1 & 24.0 & 29.3 & 25.7 & 42.0 \\
All workers & F,W,K & 23.9 & 25.0 & 27.1 & 25.2 & 38.6 \\
All workers & F,W,P & 24.4 & 22.9 & 28.4 & 22.3 & 42.3 \\
All workers & F,W,A & 24.6 & 29.8 & 27.5 & N/A & 38.9 \\
All workers & F,W,U & 23.9 & 19.2 & 29.3 & 24.4 & 43.9 \\
All workers & F,W, significant & 23.4 & 26.6 & 27.1 & 21.3 & 39.2 \\
White C. & F,W & 28.2 & 37.1 & 29.3 & 32.0 & 76.3 \\
Blue C. & F,W & 17.4 & 19.7 & 25.6 & 19.4 & 30.3 \\
Non-Man. & F,W & 20.3 & 25.4 & 26.8 & 23.4 & 36.8 \\
Non-Man. & F,W,E & 19.1 & 15.6 & 26.8 & 23.1 & 38.6 \\
Non-Man. & F,W,M & 21.0 & 25.4 & 28.7 & 31.0 & 34.3 \\
\hline
\end{tabular}

Notes:

1. Control Variables: $\mathrm{W}$ - worker characteristics; $\mathrm{F}$ - firm characteristics; $\mathrm{S}$ - skill level of firm; $\mathrm{K}$ - capital/labour ratio; $\mathrm{P}$ - firm profit; $\mathrm{E}$ - educational level of Managers; $\mathrm{M}$ - percentage of managers;

2. Calculated as twice the product of the coefficient on logged firm size and the standard deviation of firm size logged. The standard error of log employment was $1.20653,1.145184,1.542234,1.313117$, and 1.544475 for Cameroon, Ghana, Kenya, Zambia, and Zimbabwe, respectively.

Table 4: Raw Correlation of Variables with Firm Size

\begin{tabular}{lccccc}
\hline Firm Level Var. & Cameroon & Ghana & Kenya & Zambia & Zimbabwe \\
\hline CapCity & 0.09 & 0.08 & -0.03 & 0.10 & 0.13 \\
Foreign & 0.19 & 0.42 & 0.18 & 0.09 & 0.28 \\
Wood & -0.06 & 0.16 & 0.04 & -0.12 & -0.12 \\
Textile & 0.05 & -0.04 & 0.19 & 0.08 & 0.26 \\
Metal & -0.13 & 0.00 & -0.03 & -0.04 & -0.09 \\
Secondary & 0.11 & 0.11 & 0.09 & 0.12 & -0.02 \\
University & 0.04 & 0.16 & -0.23 & -0.08 & 0.15 \\
\%Skill & 0.13 & 0.14 & -0.07 & -0.01 & -0.04 \\
\%Union & 0.24 & 0.57 & 0.29 & 0.15 & 0.20 \\
K/L & 0.06 & 0.24 & 0.03 & 0.03 & 0.17 \\
VAD/L & 0.08 & 0.26 & -0.02 & 0.10 & 0.04 \\
Age & 0.35 & 0.26 & 0.21 & $\mathrm{~N} / \mathrm{A}$ & 0.30 \\
ManSec & 0.01 & 0.11 & 0.10 & 0.14 & 0.10 \\
ManUniv & 0.01 & 0.40 & 0.02 & 0.02 & 0.24 \\
Supvis & -0.05 & 0.07 & -0.32 & -0.15 & -0.22 \\
\hline
\end{tabular}


Table 5 - Alternate Profit Sharing Proxies for Ghana

\begin{tabular}{lccc}
\hline $\log ($ Size $)$ & $0.106^{* * *}$ & $0.165^{* * *}$ & $0.097^{* * *}$ \\
& $(0.019)$ & $(0.032)$ & $(0.029)$ \\
VAD/L & 1.22 & --- & --- \\
& $(5.85)$ & 441.084 & --- \\
Profitsh*VAD/L & -- & $(277.722)$ & \\
& & --- & -293.652 \\
Merit*VAD/L & --- & & $(201.182)$ \\
& & $-2.857 * * *$ & 0.000 \\
Constant & $-2.570^{* * *}$ & $(0.278)$ & $(0.000)$ \\
\hline Instrumented & $(0.180)$ & No & Yes \\
Observations & 1384 & 939 & 884 \\
F-Test & $67.99^{* * *}$ & $54.71^{* * *}$ & $35.30^{* * *}$ \\
R-squared & 0.53 & 0.57 & 0.54 \\
\hline
\end{tabular}

Table 6: Comparison of Employer Size Wage Effect of Peru to African Countries

\begin{tabular}{lccccccc}
\hline Size & US & Peru & Cameroon & Ghana & Kenya & Zambia & Zimbabwe \\
\hline $\mathbf{6 - 2 0}$ & $0.143^{+}$ & $0.291^{+}$ & 0.106 & $0.273^{* * *}$ & $0.122^{* * *}$ & 0.041 & $0.414^{* *}$ \\
$\mathbf{2 1 - 2 0 0}$ & $0.215^{+}$ & $0.340^{+}$ & $0.287^{* * *}$ & $0.424^{* * *}$ & $0.317^{* * *}$ & $0.203^{* *}$ & $0.546^{* * *}$ \\
$\mathbf{2 0 1 +}$ & $0.297^{+}$ & $0.425^{+}$ & $0.508^{* * *}$ & $0.514^{* * *}$ & $0.404^{* * *}$ & $0.398^{* * *}$ & $0.694^{* * *}$ \\
\hline
\end{tabular}

Table 7: Technology Intensity and the 'White Collar Effect'

\begin{tabular}{lcc}
\hline & Intensive & Non-Intensive \\
\hline Log(Size) & $0.053^{*}$ & $0.267^{* * *}$ \\
& $(0.029)$ & $(0.078)$ \\
WhiteC & 0.104 & 0.000 \\
& $(0.160)$ & $(0.000)$ \\
WhiteC*Log(Size) & $0.063^{*}$ & 0.040 \\
& $(0.038)$ & $(0.094)$ \\
Constant & $-2.351^{* * *}$ & $-2.731^{* * *}$ \\
& $(0.261)$ & $(0.434)$ \\
\hline Observations & 1129 & 328 \\
F-Test & 40.17 & 258.91 \\
R-squared & 0.49 & 0.49 \\
\hline
\end{tabular}




\section{Appendix A: Variable Definitions}

\begin{tabular}{ll}
\hline Variable & Definition \\
\hline Log(Hourly Wage Rate $)$ & Logged value of hourly wage rate converted to PPP \$US \\
Log(Size) & Logged value of emp loyment in firm \\
Foreign & Dummy for any foreign ownership \\
CapCity & Dummy for location in capital city \\
Wood & Dummy for operating in the Wood \& Furniture Sector \\
Metal & Dummy for operating in the Metals Sector \\
Textile & Dummy For Operating in the Textile Sector \\
Male & Dummy for males \\
Age & Age \\
Age & Squared value of age \\
Tenure & Tenure in firm \\
Tenure & Squared value of tenure \\
Primary & Dummy for highest level of education is primary \\
Secondary & Dummy for highest level of education is secondary \\
University & Dummy for highest level of education is university \\
Mgmt & Dummy for managers \\
Admin & Dummy for administrators \\
Sales & Dummy for sales persons \\
Super & Dummy for supervisors \\
Tech & Dummy for Technicians \\
Profitsh & Dummy for whether wages a percentage of sales \\
Merit & Dummy for whether receives merit/production bonus \\
\%Sec & Weighted average of workers with highest level of education is secondary \\
\%Univ & Weighted average of workers with highest level of education is university \\
Pexp & Weighted average of potential expierence \\
K/L & Value of capital stock per employee in PPP \$US \\
VAD/L & Value of value added per employee in PPP \$US \\
FAge & Age of Firm \\
Union & Percentage of workforce unionised \\
ManSec & Weighted average of managers with highest level of education is secondary \\
ManUniv & Weighted average of managers with highest level of education is university \\
Supvis & Ratio of supervisors and managers to the total workforce \\
WhiteC & Dummy for white collar workers \\
\hline & \\
\hline
\end{tabular}




\section{Appendix B: Detailed Regression Results}

Note: (1) ***, **, * denote one, five and ten per cent significance level respectively. (2) All regressions allow for correlation of errors of observations within firms.

Table B1: No Control Variables (except for year dummies)

\begin{tabular}{lccccc}
\hline & Cameroon & Ghana & Kenya & Zambia & Zimbabwe \\
\hline $\log ($ Size $)$ & $0.277^{* * *}$ & $0.250^{* * *}$ & $0.185 * * *$ & $0.243 * * *$ & $0.234 * * *$ \\
& $(0.033)$ & $(0.036)$ & $(0.024)$ & $(0.038)$ & $(0.028)$ \\
Constant & $-0.303 * *$ & $-0.958^{* * *}$ & -0.088 & $-1.606 * * *$ & $-0.892^{* * *}$ \\
& $(0.134)$ & $(0.143)$ & $(0.085)$ & $(0.148)$ & $(0.149)$ \\
\hline Observations & 1311 & 1468 & 1847 & 1187 & 1653 \\
$\mathbf{F}\left(\beta_{\mathbf{I}}=\mathbf{0}\right)$ & 35.02 & 17.36 & 123.97 & 17.63 & 35.65 \\
$\mathbf{R}^{2}$ & 0.21 & 0.18 & 0.24 & 0.11 & 0.18 \\
\hline
\end{tabular}

Table B2: Firm Characteristics Only

\begin{tabular}{lccccc}
\hline & Cameroon & Ghana & Kenya & Zambia & Zimbabwe \\
\hline $\log ($ Size $)$ & $0.234 * * *$ & $0.215^{* * *}$ & $0.157 * * *$ & $0.197 * * *$ & $0.203 * * *$ \\
& $(0.031)$ & $(0.033)$ & $(0.017)$ & $(0.032)$ & $(0.024)$ \\
Foreign & $0.135^{*}$ & $0.138^{*}$ & $0.361^{* * *}$ & $0.441^{* * *}$ & $0.218^{* *}$ \\
& $(0.077)$ & $(0.073)$ & $(0.104)$ & $(0.117)$ & $(0.089)$ \\
CapCity & $0.287 * * *$ & $0.279 * * *$ & $0.318^{* * *}$ & $0.152^{*}$ & $0.202 * * *$ \\
& $(0.081)$ & $(0.085)$ & $(0.057)$ & $(0.077)$ & $(0.059)$ \\
Wood & 0.066 & 0.082 & -0.050 & $0.373 * * *$ & -0.041 \\
& $(0.096)$ & $(0.092)$ & $(0.078)$ & $(0.124)$ & $(0.075)$ \\
Metal & $0.254 * * *$ & $0.198 * *$ & $0.121^{*}$ & $0.475^{* * *}$ & $0.435 * *$ \\
& $(0.084)$ & $(0.097)$ & $(0.069)$ & $(0.103)$ & $(0.094)$ \\
Textile & 0.118 & -0.022 & $-0.250^{* *}$ & $0.248 * *$ & $0.225 * * *$ \\
& $(0.118)$ & $(0.098)$ & $(0.098)$ & $(0.107)$ & $(0.084)$ \\
Constant & $-0.539 * * *$ & $-1.139 * * *$ & $-0.255^{* * *}$ & $-1.860 * * *$ & $-1.028 * * *$ \\
& $(0.130)$ & $(0.139)$ & $(0.071)$ & $(0.141)$ & $(0.141)$ \\
\hline Observations & 1311 & 1468 & 1847 & 1187 & 1653 \\
F( $\left.\beta_{I}=\mathbf{0}\right)$ & 22.04 & 12.24 & 53.66 & 16.62 & 20.46 \\
$\mathbf{R}^{2}$ & 0.27 & 0.25 & 0.34 & 0.21 & 0.26 \\
\hline
\end{tabular}




\section{Table B3: Worker Characteristics}

\begin{tabular}{|c|c|c|c|c|c|}
\hline & Cameroon & Ghana & Kenya & Zambia & Zimbabwe \\
\hline $\log ($ Size $)$ & $\begin{array}{l}0.098 * * * \\
(0.023)\end{array}$ & $\begin{array}{l}0.114 * * * \\
(0.030)\end{array}$ & $\begin{array}{l}0.090 * * * \\
(0.017)\end{array}$ & $\begin{array}{l}0.096 * * * \\
(0.028)\end{array}$ & $\begin{array}{l}0.138 * * * \\
(0.023)\end{array}$ \\
\hline Male & $\begin{array}{l}0.045 \\
(0.054)\end{array}$ & $\begin{array}{l}0.176 * * * \\
(0.061)\end{array}$ & $\begin{array}{l}0.206 * * * \\
(0.047)\end{array}$ & $\begin{array}{l}-0.048 \\
(0.060)\end{array}$ & $\begin{array}{l}0.122 * * \\
(0.052)\end{array}$ \\
\hline Age & $\begin{array}{l}0.067 * * * \\
(0.022)\end{array}$ & $\begin{array}{l}0.066 * * * \\
(0.010)\end{array}$ & $\begin{array}{l}0.037 * * \\
(0.015)\end{array}$ & $\begin{array}{l}0.038 * * \\
(0.016)\end{array}$ & $\begin{array}{l}0.090 * * * \\
(0.017)\end{array}$ \\
\hline $\operatorname{Age}^{2}$ & $\begin{array}{l}-0.001 * \\
(0.000)\end{array}$ & $\begin{array}{l}-0.001 * * * \\
(0.000)\end{array}$ & $\begin{array}{l}0.000 * \\
(0.000)\end{array}$ & $\begin{array}{l}0.000^{*} \\
(0.000)\end{array}$ & $\begin{array}{l}-0.001 * * * \\
(0.000)\end{array}$ \\
\hline Primary & $\begin{array}{l}0.110^{*} \\
(0.064)\end{array}$ & $\begin{array}{l}0.227^{*} \\
(0.117)\end{array}$ & $\begin{array}{l}-0.015 \\
(0.037)\end{array}$ & $\begin{array}{l}0.207 * * * \\
(0.064)\end{array}$ & $\begin{array}{l}0.037 \\
(0.054)\end{array}$ \\
\hline Secondary & $\begin{array}{l}0.457 * * * \\
(0.067)\end{array}$ & $\begin{array}{l}0.354 * * * \\
(0.126)\end{array}$ & $\begin{array}{l}0.110 * * \\
(0.044)\end{array}$ & $\begin{array}{l}0.494 * * * \\
(0.078)\end{array}$ & $\begin{array}{l}0.295 * * * \\
(0.073)\end{array}$ \\
\hline University & $\begin{array}{l}1.063^{* * * *} \\
(0.096)\end{array}$ & $\begin{array}{l}0.885^{* * * *} \\
(0.166)\end{array}$ & $\begin{array}{l}1.066^{* * * *} \\
(0.132)\end{array}$ & $\begin{array}{l}1.284 * * * \\
(0.164)\end{array}$ & $\begin{array}{l}0.799 * * \\
(0.395)\end{array}$ \\
\hline Tenure & $\begin{array}{l}0.023 * * \\
(0.009)\end{array}$ & $\begin{array}{l}0.002 \\
(0.008)\end{array}$ & $\begin{array}{l}0.008 \\
(0.007)\end{array}$ & $\begin{array}{l}0.037 * * * \\
(0.012)\end{array}$ & $\begin{array}{l}-0.003 \\
(0.008)\end{array}$ \\
\hline Tenure $^{2}$ & $\begin{array}{l}0.000 \\
(0.000)\end{array}$ & $\begin{array}{l}0.000 \\
(0.000)\end{array}$ & $\begin{array}{l}0.000 \\
(0.000)\end{array}$ & $\begin{array}{l}-0.001 * * * \\
(0.000)\end{array}$ & $\begin{array}{l}0.000 \\
(0.000)\end{array}$ \\
\hline Mgmt & $\begin{array}{l}0.546 * * * \\
(0.075)\end{array}$ & $\begin{array}{l}0.889 * * * \\
(0.085)\end{array}$ & $\begin{array}{l}0.961 * * * \\
(0.160)\end{array}$ & $\begin{array}{l}1.138 * * * \\
(0.099)\end{array}$ & $\begin{array}{l}1.210 * * * \\
(0.142)\end{array}$ \\
\hline Admin & $\begin{array}{l}0.307 * * * \\
(0.057)\end{array}$ & $\begin{array}{l}0.400 * * * \\
(0.056)\end{array}$ & $\begin{array}{l}0.518 * * * \\
(0.071)\end{array}$ & $\begin{array}{l}0.495 * * * \\
(0.078)\end{array}$ & $\begin{array}{l}0.754 * * \\
(0.355)\end{array}$ \\
\hline Sales & $\begin{array}{l}0.196^{* * * *} \\
(0.050)\end{array}$ & $\begin{array}{l}0.189 * * * \\
(0.072)\end{array}$ & $\begin{array}{l}0.243 * * \\
(0.099)\end{array}$ & $\begin{array}{l}0.269 * * * \\
(0.061)\end{array}$ & $\begin{array}{l}0.608 * * * \\
(0.059)\end{array}$ \\
\hline Super & $\begin{array}{l}0.245^{* * * *} \\
(0.075)\end{array}$ & $\begin{array}{l}0.410 * * * \\
(0.049)\end{array}$ & $\begin{array}{l}0.381 * * * \\
(0.054)\end{array}$ & $\begin{array}{l}0.292 * * * \\
(0.066)\end{array}$ & $\begin{array}{l}0.442 * * * \\
(0.051)\end{array}$ \\
\hline Tech & $\begin{array}{l}-0.023 \\
(0.062)\end{array}$ & $\begin{array}{l}0.140 * * * \\
(0.050)\end{array}$ & $\begin{array}{l}0.112 * * \\
(0.045)\end{array}$ & $\begin{array}{l}0.099 \\
(0.074)\end{array}$ & $\begin{array}{l}0.473 * * * \\
(0.076)\end{array}$ \\
\hline Constant & $\begin{array}{l}-2.083 * * * \\
(0.383)\end{array}$ & $\begin{array}{l}-2.613 * * * \\
(0.220)\end{array}$ & $\begin{array}{l}-1.152 * * * \\
(0.259)\end{array}$ & $\begin{array}{l}-2.890 * * * \\
(0.272)\end{array}$ & $\begin{array}{l}-2.935 * * * \\
(0.355)\end{array}$ \\
\hline Observations & 1311 & 1468 & 1847 & 1187 & 1653 \\
\hline $\begin{array}{l}\mathbf{F}\left(\beta_{I}=\mathbf{0}\right) \\
\mathbf{R}^{2}\end{array}$ & $\begin{array}{l}57.18 \\
0.55\end{array}$ & $\begin{array}{l}37.04 \\
0.52\end{array}$ & $\begin{array}{l}49.40 \\
0.50\end{array}$ & $\begin{array}{l}45.44 \\
0.51\end{array}$ & $\begin{array}{l}33.03 \\
0.50\end{array}$ \\
\hline
\end{tabular}




\section{Table B4: Firm Level Skill Indicators}

\begin{tabular}{llllll}
\hline & Cameroon & \multicolumn{1}{c}{ Ghana } & \multicolumn{1}{c}{ Kenya } & Zambia & \multicolumn{1}{c}{ Zimbabwe } \\
\hline $\log ($ Size $)$ & $0.100^{* * *}$ & $0.105^{* * *}$ & $0.095^{* * *}$ & $0.098^{* * *}$ & $0.136 * * *$ \\
& $(0.022)$ & $(0.030)$ & $(0.018)$ & $(0.028)$ & $(0.023)$ \\
\% Sec & $0.408^{* *}$ & 0.055 & 0.257 & 0.169 & $0.502 * *$ \\
& $(0.198)$ & $(0.235)$ & $(0.219)$ & $(0.251)$ & $(0.232)$ \\
\% Univ & $0.475^{*}$ & $2.539 * * *$ & 0.302 & -0.083 & -0.153 \\
& $(0.284)$ & $(0.756)$ & $(0.291)$ & $(0.590)$ & $(0.357)$ \\
Pexp & -0.002 & -0.001 & 0.000 & -0.005 & $0.009 * *$ \\
& $(0.005)$ & $(0.004)$ & $(0.004)$ & $(0.005)$ & $(0.004)$ \\
Constant & $-2.379 * * *$ & $-2.613 * * *$ & $-1.339 * * *$ & $-2.937 * * *$ & $-3.163 * * *$ \\
& $(0.387)$ & $(0.214)$ & $(0.313)$ & $(0.296)$ & $(0.370)$ \\
\hline Observations & 1311 & 1468 & 1847 & 1187 & 1653 \\
$\mathbf{F}\left(\beta_{\mathbf{I}}=\mathbf{0}\right)$ & 52.35 & 42.07 & 44.26 & 40.04 & 27.98 \\
$\mathbf{R}^{2}$ & 0.55 & 0.53 & 0.50 & 0.51 & 0.51 \\
\hline
\end{tabular}

Table B5: Capital-Labour Ratio

\begin{tabular}{lccccc}
\hline & Cameroon & Ghana & Kenya & Zambia & Zimbabwe \\
\hline $\mathbf{L o g}($ Size $)$ & $0.099^{* * *}$ & $0.109 * * *$ & $0.088^{* * *}$ & $0.096^{* * *}$ & $0.125^{* * *}$ \\
& $(0.023)$ & $(0.029)$ & $(0.017)$ & $(0.028)$ & $(0.023)$ \\
$\mathbf{K} / \mathbf{L}$ & 0.000 & $0.000^{* * *}$ & $0.000^{*}$ & 0.000 & $0.000^{* * *}$ \\
& $(0.000)$ & $(0.000)$ & $(0.000)$ & $(0.000)$ & $(0.000)$ \\
Constant & $-2.077 * * *$ & $-2.577 * * *$ & $-1.131 * * *$ & $-2.889 * * *$ & $-2.901 * * *$ \\
& $(0.383)$ & $(0.217)$ & $(0.256)$ & $(0.271)$ & $(0.349)$ \\
\hline Observations & 1311 & 1468 & 1847 & 1187 & 1653 \\
$\mathbf{F}\left(\beta_{\mathbf{I}}=\mathbf{0}\right)$ & 55.12 & 36.87 & 49.08 & 43.76 & 36.11 \\
$\mathbf{R}^{2}$ & 0.55 & 0.53 & 0.50 & 0.51 & 0.52 \\
\hline
\end{tabular}

Table B6: Firm Profit

\begin{tabular}{lccccc}
\hline & Cameroon & Ghana & Kenya & Zambia & Zimbabwe \\
\hline $\log ($ Size $)$ & $0.101 * * *$ & $0.100^{* * *}$ & $0.092^{* * *}$ & $0.085 * * *$ & $0.137 * * *$ \\
& $(0.023)$ & $(0.029)$ & $(0.017)$ & $(0.026)$ & $(0.023)$ \\
VAD/L & -0.463 & $9.056^{* * *}$ & 0.505 & $12.168 * * *$ & 2.573 \\
& $(0.286)$ & $(3.026)$ & $(0.377)$ & $(3.884)$ & $(1.987)$ \\
Constant & $-2.076^{* * *}$ & $-2.543 * * *$ & $-1.137 * * *$ & $-2.902 * * *$ & $-2.937 * * *$ \\
& $(0.381)$ & $(0.216)$ & $(0.258)$ & $(0.272)$ & $(0.351)$ \\
\hline Observations & 1311 & 1468 & 1847 & 1187 & 1653 \\
$\mathbf{F}\left(\beta_{\mathbf{I}}=\mathbf{0}\right)$ & 55.90 & 34.26 & 48.28 & 44.38 & 32.39 \\
$\mathbf{R}^{2}$ & 0.55 & 0.54 & 0.50 & 0.51 & 0.51 \\
\hline
\end{tabular}


Table B7: Firm Age

\begin{tabular}{lccccc}
\hline & Cameroon & Ghana & Kenya & Zambia & Zimbabwe \\
\hline $\log ($ Size $)$ & $0.102^{* * *}$ & $0.130^{* * *}$ & $0.089^{* * *}$ & N/A & $0.126^{* * * *}$ \\
& $(0.023)$ & $(0.031)$ & $(0.018)$ & N/A & $(0.024)$ \\
FAge & -0.002 & $-0.006 * * *$ & 0.001 & N/A & 0.003 \\
& $(0.003)$ & $(0.002)$ & $(0.002)$ & N/A & $(0.002)$ \\
Constant & $-2.073 * * *$ & $-2.573 * * *$ & $-1.168 * * *$ & N/A & $-2.928 * * *$ \\
& $(0.378)$ & $(0.209)$ & $(0.269)$ & N/A & $(0.351)$ \\
\hline Observations & 1311 & 1408 & 1750 & N/A & 1653 \\
$\mathbf{F}\left(\beta_{\mathbf{I}}=\mathbf{0}\right)$ & 56.33 & 35.91 & 44.14 & N/A & 31.97 \\
$\mathbf{R}^{2}$ & 0.55 & 0.54 & 0.50 & N/A & 0.51 \\
\hline
\end{tabular}

Table B8: Firm Level Union Density

\begin{tabular}{lccccc}
\hline & Cameroon & Ghana & Kenya & Zambia & Zimbabwe \\
\hline $\log ($ Size $)$ & $0.099^{* * *}$ & $0.084^{* *}$ & $0.095^{* * *}$ & $0.093^{* *}$ & $0.142^{* * * *}$ \\
& $(0.024)$ & $(0.035)$ & $(0.018)$ & $(0.037)$ & $(0.024)$ \\
Union & 0.000 & 0.000 & -0.001 & 0.000 & 0.000 \\
& $(0.001)$ & $(0.000)$ & $(0.001)$ & $(0.001)$ & $(0.001)$ \\
Constant & $-2.025^{* * *}$ & $-2.531^{* * *}$ & $-1.163^{* * *}$ & $-2.915^{* * *}$ & $-2.937 * * *$ \\
& $(0.382)$ & $(0.226)$ & $(0.259)$ & $(0.299)$ & $(0.356)$ \\
\hline Observations & 1300 & 1447 & 1847 & 1045 & 1643 \\
$\mathbf{F}\left(\beta_{\mathbf{I}}=\mathbf{0}\right)$ & 55.21 & 33.44 & 46.81 & 37.97 & 31.69 \\
$\mathbf{R}^{2}$ & 0.55 & 0.52 & 0.50 & 0.51 & 0.50 \\
\hline
\end{tabular}

Table B9: Firm, Worker and Other Significant Controls

\begin{tabular}{lccccc}
\hline & Cameroon & Ghana & Kenya & Zambia & Zimbabwe \\
\hline $\log ($ Size $)$ & $0.097^{* * *}$ & $0.116^{* * *}$ & $0.088^{* * *}$ & $0.081^{* * *}$ & $0.127^{* * *}$ \\
& $(0.022)$ & $(0.032)$ & $(0.017)$ & $(0.028)$ & $(0.022)$ \\
Constant & $-2.383^{* * *}$ & $-2.532^{* * *}$ & $-1.131^{* * *}$ & $-2.854 * * *$ & $-3.025^{* * * *}$ \\
& $(0.384)$ & $(0.215)$ & $(0.256)$ & $(0.278)$ & $(0.354)$ \\
\hline Observations & 1311 & 1408 & 1847 & 1187 & 1653 \\
$\mathbf{F}\left(\beta_{\mathbf{I}}=\mathbf{0}\right)$ & 52.23 & 44.20 & 49.08 & 43.47 & 35.07 \\
$\mathbf{R}^{2}$ & 0.55 & 0.55 & 0.50 & 0.51 & 0.52 \\
\hline
\end{tabular}

Table B10: Non-Managerial Workers

\begin{tabular}{lccccc}
\hline & Cameroon & Ghana & Kenya & Zambia & Zimbabwe \\
\hline $\log ($ Size $)$ & $0.084^{* * *}$ & $0.111^{* * *}$ & $0.087 * * *$ & $0.089^{* * *}$ & $0.119^{* * *}$ \\
& $(0.024)$ & $(0.031)$ & $(0.017)$ & $(0.028)$ & $(0.023)$ \\
Constant & $-2.099^{* * *}$ & $-2.405^{* * *}$ & $-1.201 * * *$ & $-2.653^{* * *}$ & $-2.921^{* * *}$ \\
& $(0.397)$ & $(0.232)$ & $(0.267)$ & $(0.255)$ & $(0.372)$ \\
\hline Observations & 1165 & 1243 & 1644 & 926 & 1399 \\
$\mathbf{F}\left(\beta_{\mathbf{I}}=\mathbf{0}\right)$ & 38.74 & 24.39 & 31.95 & 30.92 & 28.61 \\
$\mathbf{R}^{2}$ & 0.51 & 0.43 & 0.46 & 0.38 & 0.44 \\
\hline
\end{tabular}


Table B11: Non-Managerial Workers - With Managerial Skill Level Indicators

\begin{tabular}{llllll}
\hline & Cameroon & \multicolumn{1}{c}{ Ghana } & \multicolumn{1}{c}{ Kenya } & Zambia & \multicolumn{1}{c}{ Zimbabwe } \\
\hline $\log ($ Size $)$ & $0.079 * * *$ & $0.068^{* *}$ & $0.087 * * *$ & $0.088^{* * *}$ & $0.125^{* * *}$ \\
& $(0.025)$ & $(0.030)$ & $(0.018)$ & $(0.027)$ & $(0.024)$ \\
Mansec & 0.057 & $0.273 * *$ & 0.033 & 0.111 & -0.028 \\
& $(0.079)$ & $(0.109)$ & $(0.081)$ & $(0.112)$ & $(0.094)$ \\
Manuniv & $0.257 * *$ & $0.772 * * *$ & -0.027 & -0.031 & -0.431 \\
& $(0.114)$ & $(0.266)$ & $(0.159)$ & $(0.137)$ & $(0.281)$ \\
Constant & $-2.146^{* * *}$ & $-2.326^{* * *}$ & $-1.212 * * *$ & $-2.695 * * *$ & $-2.880^{* * *}$ \\
& $(0.401)$ & $(0.225)$ & $(0.273)$ & $(0.258)$ & $(0.372)$ \\
\hline Observations & 1165 & 1243 & 1644 & 926 & 1399 \\
F( $\left.\beta_{\mathbf{I}}=\mathbf{0}\right)$ & 38.81 & 24.38 & 30.85 & 29.29 & 28.11 \\
$\mathbf{R}^{2}$ & 0.51 & 0.45 & 0.46 & 0.38 & 0.45 \\
\hline
\end{tabular}

Table B12: Non-Managerial Workers - With Monitoring Intensity Indicator

\begin{tabular}{lccccc}
\hline & Cameroon & Ghana & Kenya & Zambia & Zimbabwe \\
\hline $\log ($ Size $)$ & $0.087 * * *$ & $0.111^{* * *}$ & $0.093 * * *$ & $0.118^{* * *}$ & $0.111^{* * *}$ \\
& $(0.024)$ & $(0.031)$ & $(0.022)$ & $(0.035)$ & $(0.024)$ \\
Supvis & 0.098 & 0.483 & 0.049 & 0.255 & -0.227 \\
& $(0.138)$ & $(0.338)$ & $(0.104)$ & $(0.174)$ & $(0.158)$ \\
Constant & $-2.161 * * *$ & $-2.380^{* * *}$ & $-1.252^{* * *}$ & $-2.912 * * *$ & $-2.725 * *$ \\
& $(0.391)$ & $(0.230)$ & $(0.267)$ & $(0.315)$ & $(0.431)$ \\
\hline Obs ervations & 1165 & 1243 & 1644 & 926 & 1399 \\
$\mathbf{F}\left(\beta_{\mathbf{I}}=\mathbf{0}\right)$ & 37.08 & 25.79 & 30.31 & 30.94 & 28.07 \\
$\mathbf{R}^{2}$ & 0.51 & 0.43 & 0.46 & 0.39 & 0.45 \\
\hline
\end{tabular}

Table B13: White Collar Workers

\begin{tabular}{lccccc}
\hline & Cameroon & Ghana & Kenya & Zambia & Zimbabwe \\
\hline $\log ($ Size $)$ & $0.117 * * *$ & $0.162^{* * *}$ & $0.095^{* * *}$ & $0.122^{* * *}$ & $0.247 * * *$ \\
& $(0.028)$ & $(0.041)$ & $(0.025)$ & $(0.037)$ & $(0.033)$ \\
Constant & $-1.927 * * *$ & $-2.126^{* * *}$ & $-1.133 * * *$ & $-2.669 * * *$ & $-2.706^{* * *}$ \\
& $(0.487)$ & $(0.368)$ & $(0.419)$ & $(0.420)$ & $(0.581)$ \\
\hline Observations & 642 & 594 & 669 & 719 & 555 \\
$\mathbf{F}\left(\beta_{\mathbf{I}}=\mathbf{0}\right)$ & 48.25 & 22.71 & 33.68 & 31.95 & 21.71 \\
$\mathbf{R}^{2}$ & 0.59 & 0.46 & 0.50 & 0.55 & 0.50 \\
\hline
\end{tabular}


Table B14: Blue Collar Workers

\begin{tabular}{lccccc}
\hline & Cameroon & Ghana & Kenya & Zambia & Zimbabwe \\
\hline $\log ($ Size $)$ & $0.072^{* *}$ & $0.086^{* *}$ & $0.083^{* * *}$ & $0.074 * *$ & $0.098^{* * *}$ \\
& $(0.029)$ & $(0.034)$ & $(0.018)$ & $(0.030)$ & $(0.024)$ \\
Constant & $-2.254 * * *$ & $-2.520 * * *$ & $-1.045^{* * *}$ & $-2.718^{* * *}$ & $-2.482^{* * *}$ \\
& $(0.511)$ & $(0.259)$ & $(0.321)$ & $(0.335)$ & $(0.372)$ \\
\hline Observations & 669 & 874 & 1178 & 468 & 1098 \\
$\mathbf{F}\left(\beta_{\mathbf{I}}=\mathbf{0}\right)$ & 27.86 & 15.57 & 25.82 & 12.62 & 6.13 \\
$\mathbf{R}^{2}$ & 0.44 & 0.37 & 0.45 & 0.22 & 0.30 \\
\hline
\end{tabular}




\section{IZA Discussion Papers}

\begin{tabular}{|c|c|c|c|c|}
\hline No. & Author(s) & Title & Area & Date \\
\hline 644 & $\begin{array}{l}\text { J. D. Brown } \\
\text { J. S. Earle }\end{array}$ & $\begin{array}{l}\text { Job Reallocation and Productivity Growth Under } \\
\text { Alternative Economic Systems and Policies: } \\
\text { Evidence from the Soviet Transition }\end{array}$ & 4 & $11 / 02$ \\
\hline 645 & $\begin{array}{l}\text { M. Karanassou } \\
\text { H. Sala } \\
\text { D. J. Snower }\end{array}$ & $\begin{array}{l}\text { Long-Run Inflation-Unemployment Dynamics: } \\
\text { The Spanish Phillips Curve and Economic Policy }\end{array}$ & 3 & $11 / 02$ \\
\hline 646 & $\begin{array}{l}\text { L. Graham } \\
\text { D. Snower }\end{array}$ & The Return of the Long-Run Phillips Curve & 3 & $11 / 02$ \\
\hline 647 & $\begin{array}{l}\text { C. Grund } \\
\text { D. Sliwka }\end{array}$ & Envy and Compassion in Tournaments & 1 & $11 / 02$ \\
\hline 648 & $\begin{array}{l}\text { C. Schnabel } \\
\text { T. Schank } \\
\text { J. Wagner }\end{array}$ & $\begin{array}{l}\text { Works Councils - Sand or Grease in the } \\
\text { Operation of German Firms? }\end{array}$ & 3 & $11 / 02$ \\
\hline 649 & $\begin{array}{l}\text { J. van Ours } \\
\text { J. Veenman }\end{array}$ & $\begin{array}{l}\text { From Parent to Child: Early Labor Market } \\
\text { Experiences of Second-Generation Immigrants } \\
\text { in the Netherlands }\end{array}$ & 1 & $11 / 02$ \\
\hline 650 & $\begin{array}{l}\text { H. Battu } \\
\text { P. J. Sloane }\end{array}$ & Overeducation and Ethnic Minorities in Britain & 2 & $11 / 02$ \\
\hline 651 & E. Schlicht & $\begin{array}{l}\text { Social Evolution, Corporate Culture, and } \\
\text { Exploitation }\end{array}$ & 3 & $11 / 02$ \\
\hline 652 & E. Plug & $\begin{array}{l}\text { How Do Parents Raise the Educational } \\
\text { Attainment of Future Generations? }\end{array}$ & 5 & $11 / 02$ \\
\hline 653 & $\begin{array}{l}\text { W. Groot } \\
\text { E. Plug } \\
\text { H. Maassen van den } \\
\text { Brink }\end{array}$ & $\begin{array}{l}\text { Money for Health: The Compensating Variation } \\
\text { of Cardiovascular Diseases }\end{array}$ & 6 & $11 / 02$ \\
\hline 654 & $\begin{array}{l}\text { C. Ruhm } \\
\text { U. G. Gerdtham }\end{array}$ & $\begin{array}{l}\text { Deaths Rise in Good Economic Times: Evidence } \\
\text { From the OECD }\end{array}$ & 2 & $11 / 02$ \\
\hline 655 & $\begin{array}{l}\text { W. Arulampalam } \\
\text { R. A. Naylor } \\
\text { J. P. Smith }\end{array}$ & $\begin{array}{l}\text { Effects of In-Class Variation and Student Rank } \\
\text { on the Probability of Withdrawal: Cross-Section } \\
\text { and Time-Series Analysis for UK University } \\
\text { Students }\end{array}$ & 2 & $11 / 02$ \\
\hline 656 & $\begin{array}{l}\text { T. Beissinger } \\
\text { O. Büsse }\end{array}$ & $\begin{array}{l}\text { The Impact of the Unemployment Benefit } \\
\text { System on International Spillover Effects }\end{array}$ & 2 & $11 / 02$ \\
\hline 657 & $\begin{array}{l}\text { A. Kugler } \\
\text { J. F. Jimeno } \\
\text { V. Hernanz }\end{array}$ & $\begin{array}{l}\text { Employment Consequences of Restrictive } \\
\text { Permanent Contracts: Evidence from Spanish } \\
\text { Labor Market Reforms }\end{array}$ & 2 & $11 / 02$ \\
\hline 658 & $\begin{array}{l}\text { G. Brunello } \\
\text { R. Winter-Ebmer }\end{array}$ & $\begin{array}{l}\text { Why Do Students Expect to Stay Longer in } \\
\text { College? Evidence from Europe }\end{array}$ & 5 & $12 / 02$ \\
\hline 659 & $\begin{array}{l}\text { D. Byrne } \\
\text { E. Strobl }\end{array}$ & $\begin{array}{l}\text { Defining Unemployment in Developing } \\
\text { Countries: Evidence from Trinidad and Tobago }\end{array}$ & 4 & $12 / 02$ \\
\hline 660 & $\begin{array}{l}\text { E. Strobl } \\
\text { R. Thornton }\end{array}$ & $\begin{array}{l}\text { Do Large Employers Pay More in Developing } \\
\text { Countries? The Case of Five African Countries }\end{array}$ & 4 & $12 / 02$ \\
\hline
\end{tabular}

An updated list of IZA Discussion Papers is available on the center's homepage www.iza.org. 